\title{
PENGUATAN PENGETAHUAN KEWARGANEGARAAN (CIVIC KNOWLEDGE) DALAM MENINGKATKAN KESADARAN HUKUM MAHASISWA
}

\author{
Aprillio Poppy Belladonna ${ }^{1}$, Selly Novia Anggraena ${ }^{2}$ \\ Sekolah Tinggi Keguruan Ilmu Pendidikan Pasundan \\ email: aprillio_poppy@yahoo.co.id
}

\begin{abstract}
Abstrak
Tujuan dari penelitian ini adalah untuk mengetahui bagaimana penguatan pengetahuan kewarganegaraan (civic knowledge) dalam meningkatkan kesadaran hukum mahasiswa. Metode penelitian yang digunakan dalam penelitian ini adalah metode deskriptif sedangkanpengumpulan data dilakukan melalui wawancara, observasi studi dokumentasi dan studi literatur. Adapun hasil penelitian menunjukkan bahwa penguatan pengetahuan melalui mata kuliah pendidikan kewarganegaraan merupakan langkah yang baik, namun untuk membangun kesadaran hukum perlu dibangun dengan habituasi atau pembiasaan dalam kehidupan seharihari sehingga yang dibangun bukan hanya sebatas pengetahuan saja. Kesadaran hukum mahasiswa STKIP Pasundan sudah tergolong baik terlihat dari bagaimana mereka mematuhi peraturan yang berlaku di lingkungan kampus. Hasil penelitian juga menunjukkan bahwa terjadi perbedaan kepatuhan atau ketaatan terhadap hukum didasarkan pada tempat.
\end{abstract}

Kata kunci: Pengetahuan Kewarganegaraan, Kesadaran hukum, Pendidikan Kewarganegaraan

\begin{abstract}
Objectives of the study are to find how the form of a strengthening citizenship as a capital investment knowledge ( civic knowledge) in enhanced legal awareness in in STKIP Pasundan.Research methods that were used in this research was a method of a case study with a qualitative approach was adopted, to understand and explain the various problem in depth data collection was carried out with the study documentation, observation, and conducting interviews. As for the result of research studies show that the rupiah to appreciate or knowledge through the of the eye tuition education citizenship as a capital investment is a good step, however in order to build legal awareness in need to artificially formed by dams habituation or pembiasaan in the life of sehari-hari so that the not built and limited only to inform the level of knowledge of only a matter of time .Legal awareness in what the students are stkip pasundan is considered to be good looks of how made them to excel by the applicable regulation in the vicinity of the campus.The results of the study also found that there are tampaknya ada komponen kalimat kata adherence to or observance of to the law of based on the place.
\end{abstract}

Keywords: Civic Knowledge, Law Awareness, Civic Education

\section{PENDAHULUAN}

Pendidikan mempunyai peranan yang sangat penting guna menunjang kehidupan manusia, dengan pendidikan kualitas manusia dapat meningkat dan manusia dapat berkembang serta tidak terbelakang. Pendidikan juga digunakan sebagai jalan untuk mencerdaskan kehidupan bangsa yang merupakan salah satu cita-cita luhur bangsa Indonesia yang tertuang di dalam alinea keempat Pembukaan Undang-undang Dasar 1945.

Sejalan dengan hal tersebut, di samping pentingnya pendidikan ternyata ada tantangan yang harus kita hadapi di dalam sistem pendidikan nasional kita, salah satunya berkenaan dengan Globalisasi. Era globalisasi merupakan sebuah realitas yang harus dihadapi oleh masyarakat Indonesia. Pengaruh globalisasi saat ini dirasa sangat kuat dan terbuka, dampak globalisasi sendiri di satu sisi memang memberikan dampak positif seperti kemajuan ilmu pengetahuan dan teknologi, namun disisi lain globalisasi juga memberikan dampak negatif, salah satunya 
berdampak terhadap perilaku manusia. Maftuh (2008, p. 135) mengemukakan bahwa kehidupan masyarakat Indonesia, khususnya generasi muda pada era globalisasi ini mendapat pengaruh yang sangat kuat dari nilai-nilai budaya luar, sehingga mulai banyak sikap dan perilaku yang tidak sejalan dengan nilai-nilai Pancasila.

Masyarakat kita, khususnya anak muda banyak yang lupa akan identitas diri sebagai bangsa Indonesia, seperti lunturnya sikap toleransi, keramahtamahan, penghormatan pada yang lebih tua juga pergaulan bebas serta sikap individualis. Hal ini sejalan dengan yang diungkapkan oleh Rusniati (2015, p. 109) yang mengemukakan bahwa "Di era globalisasi ini, dunia pendidikan pada umumnya sedang menghadapi berbagai tantangan, salah satunya globalisasi di bidang budaya, etika dan moral sebagai akibat dari kemajuan teknologi di bidang transportasi dan informasi".

Fenomena-fenomena yang sering terjadi dan menjadi masalah serius yang sering kita jumpai saat ini adalah mengenai masalah kemerosotan moral, banyak perilaku menyimpang yang dilakukan oleh masyarakat khususnya generasi muda seperti pergaulan bebas, tindakan asusila, penyalahgunaan narkotika, pelanggaran lalu lintas, demonstrasi secara anarkis, tawuran serta perilaku-perilaku lain yang berlainan dengan nilai-nilai yang berlaku dalam masyarakat. Ironisnya perilaku-perilaku menyimpang tersebut banyak dilakukan oleh seorang mahasiswa, padahal mahasiswa sebagai kaum intelektual seharusnya dapat menjadi contoh yang baik bagi masyarakat. Berikut merupakan data dari media massa yang menunjukkan banyaknya perilakuperilaku menyimpang yang dilakukan mahasiswa :

1. Mahasiswa dan Tukang Sablon Jadi Tersangka Demo Ricuh di Yogya. (Tempo.co, Kamis 03/05/2018)

2. Gara-gara Baut Motor, Mahasiswa Aniaya Temannya. (Detiknews, Sabtu, 25/08/2018)

3. Mahasiswa Purwokerto Dibekuk Usai 8 Kali Mencuri. (Satelitpost.com, Selasa 03/04/2018)

4. Kaum Milenial (pelajar dan mahasiswa) Paling Banyak Melanggar Aturan Lalu Lintas di Surabaya (Surya.co.id, Selasa 26/03/2018)

5. Mahasiswa Di Surabaya Diringkus Polisi Setelah Lakukan Hal Tak Senonoh Pada 4 Bocah Laki-laki. (Tribunnews.com, Selasa 28/08/2018)

Fenomena-fenomena tersebut merupakan bentuk perilaku yang tidak sesuai dengan nilainilai yang berlaku di masyarakat yang secara eksplisit menunjukkan terjadinya kemerosotan moral yang melanda generasi muda khususnya dikalangan mahasiswa. Padahal sejatinya mahasiswa sebagai bagian dari masyarakat yang juga merupakan generasi penerus bangsa diharapkan memiliki kekuatan baik secara intelektual maupun moral. 
Sejalan dengan hal tersebut, Lickona (Sari, 2014, p. 17) mengemukakan bahwa ada 10 (sepuluh) aspek degradasi moral yang melanda suatu negara yang merupakan tanda-tanda kehancuran suatu bangsa. Kesepuluh tanda tersebut adalah:

a. Meningkatnya kekerasan pada remaja;

b. Penggunaan kata-kata yang memburuk;

c. Pengaruh peer group (rekan kelompok) yang kuat dalam tindak kekerasan;

d. Meningkatnya penggunaan narkoba, alkohol dan seks bebas;

e. Kaburnya batasan moral baik-buruk;

f. Menurunnya etos kerja;

g. Rendahnya rasa hormat kepada orang tua dan guru;

h. Rendahnya rasa tanggung jawab individu dan warga negara;

i. Membudayanya ketidakjujuran;

j. Adanya saling curiga dan kebencian di antara sesama.

Masalah-masalah perilaku menyimpang yang dilakukan mahasiswa banyak menunjukkan adanya pelanggaran hukum yang kini marak terjadi seperti yang sudah disebutkan sebelumnya, maraknya pelanggaran hukum yang dilakukan oleh mahasiswa tersebut merupakan bukti dari masih rendahnya kesadaran hukum dikalangan mahasiswa. Menurut Mertokusumo (Arliman, 2015, p. 219) bahwa kesadaran hukum adalah kesadaran tentang apa yang seyogyanya kita lakukan atau perbuat atau yang seyogyanya tidak kita lakukan atau perbuat terutama terhadap orang lain, sehingga dapat dikatakan bahwa kesadaran hukum mengandung sikap toleransi.

Dengan demikian kesadaran hukum merupakan suatu kesadaran yang ada di dalam diri setiap individu, untuk patuh dan taat kepada setiap peraturan atau hukum yang berlaku yang dimana memang dirasa bahwa hukum tersebut baik dan adil. Rasa kesadaran hukum dapat menciptakan ketertiban, kedamaian, ketentraman, serta keadilan di dalam masyarakat. Oleh sebab itu, penting untuk memiliki rasa kesadaran hukum karena bagaimanapun negara Indonesia merupakan negara hukum yang hampir semua aspek di dalamnya diatur oleh hukum.

Sejalan dengan hal tersebut Yulia Wiranti Penyuluh Hukum Ahli Madya di Badan Pembinaan Hukum Nasional dalam kegiatan Masa Perkenalan Calon Anggota (Maperca), Jakarta Selatan menyatakan :

"Kesadaran hukum di kalangan generasi muda sangat diperlukan, mahasiswa dan pelajar merupakan generasi penerus bangsa. Kesadaran hukum yang tinggi di kalangan mahasiswa dan pelajar dapat memberikan kenyamanan dan kedisiplinan khususnya di kampus/sekolah dan pada umumnya di lingkungan masyarakat dan negara”.(www.bphn.go.id, Sabtu, 08 Oktober 2016).

Terlihat bagaimana pentingnya peran mahasiswa dalam pembangunan suatu bangsa. Kemajuan suatu bangsa dapat dilihat dari tingkat kesadaran hukum dan ketaatan hukum warganya. Semakin tinggi kesadaran hukum dan ketaatan hukum penduduk suatu negara, akan semakin tertib kehidupan bermasyarakat dan bernegara. 
Kenyataan tentang akutnya problem moral yang ada kemudian menempatkan pentingnya pendidikan yang memuat pembelajaran yang dapat membentuk perilaku, membina sikap dan moral serta memberikan pendidikan hukum sebagai upaya untuk meningkatkan kesadaran hukum dikalangan mahasiswa, dan, salah satu usaha untuk membentuk perilaku, membina sikap dan moral serta memberikan pendidikan hukum guna menanamkan rasa kesadaran hukum tersebut salah satunya melalui pembelajaran Pendidikan Kewarganegaraan. Chamim (Aryani \& Susatim, 2010, p. 40) mengemukakan bahwa :

Pendidikan Kewarganegaraan bagi bangsa Indonesia berarti pendidikan pengetahuan, sikap, mental, nilai-nilai, dan perilaku yang menjunjung tinggi demokrasi sehingga terwujud warga masyarakat yang demokratis dan mampu menjaga persatuan dan integritas bangsa guna mewujudkan Indonesia yang kuat, sejahtera, serta demokrasi.

Pendidikan Kewarganegaraan merupakan mata pelajaran wajib pada jenjang sekolah dasar dan sekolah menengah. Tidak hanya pada jenjang Sekolah Dasar dan Sekolah Menengah saja namun Pendidikan Kewarganegaraan pun menjadi mata kuliah wajib pada jenjang Perguruan Tinggi. Berdasarkan Pasal 35 ayat 3 (Undang-Undang Republik Indonesia Nomor 12 Tahun 2012 Tentang Pendidikan Tinggi, 2012) menerangkan bahwa

Kurikulum Pendidikan Tinggi wajib memuat mata kuliah: Agama, Pancasila, Kewarganegaraan, dan Bahasa Indonesia. Yang dimaksud dengan "mata kuliah kewarganegaraan" adalah pendidikan yang mencakup Pancasila,Undang-Undang Dasar Negara Republik Indonesia Tahun 1945, Negara Kesatuan Republik Indonesia dan Bhineka Tunggal Ika untuk membentuk Mahasiswa menjadi warga negara yang memiliki rasa kebangsaan dan cinta tanah air.

Udin \& Mansur (Dwiyatmi, et al., 2012, p. 6) mengemukakan bahwa tujuan diadakannya Pendidikan Kewarganegaraan di perguruan tinggi telah dirumuskan dalam visi dan misi dari Pendidikan Kewarganegaraan itu sendiri. Adapun Visi dan Misi tersebut ialah

Visi dan Misi Mata Kuliah Pendidikan Kewarganegaraan di Perguruan Tinggi merupakan sumber nilai dan pedoman dalam pengembangan dan penyelenggaraan program studi, guna mengantarkan mahasiswa memantapkan kepribadiannya sebagai manusia seutuhnya. Konkrit nya membantu mahasiswa memantapkan kepribadiannya, agar secara konsisten mampu mewujudkan nilai-nilai dasar Pancasila, rasa kebangsaan dan cinta tanah air dalam menguasai, menerapkan dan mengembangkan ilmu pengetahuan, teknologi dan seni dengan rasa tanggung jawab dan bermoral.

Menurut Erwin (2012, p. 5) kompetensi yang diharapkan dengan adanya Pendidikan Kewarganegaraan ini dapat dipilah atas tiga klasifikasi yaitu

Pertama, paling tidak dapat memunculkan civic knowledge, yakni orang yang kenal dengan Pendidikan Kewarganegaraan dapat memiliki pengetahuan tentang kebangsaan dan kewarganegaraan. Kedua, dalam tingkatan civic dispositions, dimana orang mengerti seluk beluk tentang kebangsaan dan kewarganegaraan akan dapat menerapkan pengetahuan yang diperoleh pada tingkatan civic knowledge untuk diterapkan dalam kehidupan sehari-hari. Ketiga, untuk tingkatan yang paling ber-action ada pada civic skill. Dimana pihak yang 
berada pada tingkatan ini telah mampu mengaplikasikannya dalam bentuk keterampilan seperti orang-orang yang dapat berperan dalam pembuatan kebijakan publik yang dapat berguna bagi orang-orang banyak seperti orang-orang yang bergabung dalam legislatif ataupun orang-orang yang dapat melakukan pengawasan terhadap jalannya pemerintahan seperti aktivis lembaga-lembaga swadaya masyarakat.

Sedangkan menurut Dwiyatmi, dkk.(2012, p. 10) standar kompetensi yang wajib dikuasai mahasiswa setelah mendapatkan pembelajaran Pendidikan Kewarganegaraan di perguruan tinggi adalah "Mahasiswa memiliki pengetahuan tentang kewarganegaraan demokratis dan mampu menerapkan pengetahuan nilai-nilai dan keterampilan tersebut dalam kehidupan sehari-hari; memilki kepribadian yang mantap; berpikir kritis; bersikap rasional, etis, estetis, dan dinamis; berpandangan luas; dan bersikap demokratis yang berkeadaban."

Dengan demikian dari pemaparan yang sudah dipaparkan di atas terlihat pentingnya pembelajaran Pendidikan Kewarganegaraan di jenjang perguruan tinggi tersebut. Ubaedillah, dkk. (2010, p. 10) mengemukakan bahwa "Setelah mahasiswa mengikuti pembelajaran Pendidikan Kewarganegaraan dengan baik dan benar diharapkan mereka akan menjadi warga negara Indonesia yang memiliki kemampuan untuk melakukan perubahan di tengah masyarakat, melakukan transfer of learning (proses pembelajaran diri), transfer of value (proses pengejawantahan nilai-nilai), dan transfer of principles (proses pengalihan prinsip-prinsip) demokrasi, HAM dan masyarakat madani dalam kehidupan nyata”.

Setelah mahasiswa mendapatkan pembelajaran pendidikan kewarganegaraan, hasil dari proses pembelajaran mahasiswa juga dapat meningkatkan pengetahuan kewarganegaraan (civic knowledge) yang berguna untuk memberikan arahan untuk bagaimana seharusnya mereka bertindak untuk menjadi warga negara yang baik dan cerdas (smart and good citizenship).

Warga negara yang baik menurut Azis Wahab (Sofyan \& Dadang, 2015, p. 185) ialahWarga negara yang memahami dan mampu melaksanakan dengan baik hak-hak dan kewajibannya sebagai individu warga Negara yang memiliki kepekaan dan tanggung jawab sosial, mampu memecahkan masalah-masalahnya sendiri dan juga masalah-masalah kemasyarakatan secara cerdas sesuai dengan fungsi dan perannya (socially sensitive, socially responsible, dan socially intelligence), memilki sikap disiplin pribadi, mampu berfikir kritis kreatif, dan inovatif agar dicapai kualitas pribadi dan perilaku warga Negara dan warga masyarakat yang baik (socio civic behavior dan desirable personal qualities).

Salah satu ciri warga negara yang baik adalah memahami hak-hak dan kewajibannya. Dengan demikian dapat dikatakan bahwa sebagai warga negara yang baik kita harus dapat menyeimbangkan antara hak dan kewajiban, tidak melulu menuntut hak tetapi lupa akan kewajibannya. Salah satu kewajiban warga Negara tertuang dalam Pasal 27 ayat (1) (UndangUndang NRI 1945, 1945) yang berbunyi: "Segala warga negara bersamaan kedudukannya di 
dalam hukum dan pemerintahan dan wajib menjunjung hukum dan pemerintahan itu dengan tidak ada kecualinya".

Maka dengan demikian jelaslah bahwa sebagai warga negara yang baik kita harus dapat mentaati setiap hukum yang ada dan berlaku. Terlihat bagaimana pentingnya memilki rasa kesadaran hukum agar terciptanya ketertiban dan kedamaian dalam kehidupan bermasyarakat. Salah satu usaha menanamkan kesadaran hukum adalah dengan memberikan pendidikan hukum yang dimana untuk pendidikan hukum sendiri sudah terintegrasi dalam pembelajaran Pendidikan Kewarganegaraan.

Pendidikan Kewarganegaraan memberikan pengaruh yang sangat besar terhadap proses pensosialisasian hukum. Pendidikan Kewarganegaraan adalah jendela pengetahuan hukum yang diperoleh secara formal di sekolah dimulai dari pendidikan dasar hingga perguruan tinggi. Sehingga ketika individu tersebut telah bermasyarakat, individu tersebut telah mengetahui hukum. Soemardjan (Hardianto, 2017, p. 18) mengemukakan bahwa "Salah satu faktor dalam mempengaruhi kesadaran hukum, yaitu usaha-usaha menanamkan hukum di dalam masyarakat, yaitu penggunaan tenaga manusia, alat-alat, organisasi, dan metode agar masyarakat mengetahui, menghargai mengakui dan mentaati hukum”.

Dengan demikian dapat disimpulkan bahwa pembelajaran Pendidikan Kewarganegaraan berpengaruh terhadap pensosialisasian hukum, yang dimana cara pensosialisasian hukum tersebut melalui pembelajaran di sekolah atau di perguruan tinggi. Melalui pembelajaran pendidikan tersebut, peserta didik bisa mendapatkan pengetahuan kewarganegaraan salah satunya pengetahuan tentang hukum. Hal tersebut didasarkan oleh karena Pendidikan Kewarganegaraan memiliki daya jelajah dalam ruang lingkup yang luas mengenai kehidupan berbangsa dan bernegara.

Sebagai bagian dari masyarakat mahasiswa perlu menyadari adanya hukum-hukum yang berlaku di dalam masyarakat. Dengan demikian untuk mewujudkan proses internalisasi hukum dalam masyarakat adanya pendidikan hukum adalah suatu keharusan. Bila seseorang memiliki pengetahuan tentang hukum, diharapkan hal tersebut dapat menciptakan rasa kesadaran hukum setiap individu, sehingga terwujud tujuan hukum itu sendiri.

Sekolah Tinggi Keguruan dan Ilmu Pendidikan Pasundan merupakan salah satu perguruan tinggi yang berada di wilayah Kota Cimahi. Sebagai salah satu perguruan tinggi yang melaksanakan kegiatan mata kuliah Pendidikan Kewarganegaraan, STKIP Pasundan sangat mendukung langkah-langkah yang diambil oleh pemerintah untuk mengembangkan kehidupan bernegara dan berbangsa di kalangan generasi muda, dan mahasiswa pada khususnya.

Sama halnya seperti lembaga pendidikan tinggi yang lain, di STKIP Pasundan berlaku aturan-aturantertentu yang harus dipatuhi dan dilaksanakan oleh seluruh sivitas akademika, baik 
itu rektor, para dosen, mahasiswa, dan pegawai universitas. Aturan hukum tersebut diberlakukan demi mewujudkan aktivitas akademika yang teratur, kondusif, dan mengatur ketertiban di lingkungan kampus. Akan tetapi, dalam pelaksanaannya masih ada mahasiswa yang melanggar aturan-aturan yang berlaku di lingkungan kampus.

Dengan diberikannya mata kuliah Pendidikan Kewarganegaraan, diharapkan dapat menguatkan pengetahuan kewarganegaraan dikalangan mahasiswa yang dimana hal tersebut dapat meningkatkan kesadaran hukum dikalangan mahasiswa, mencegah mereka melakukan tindakan yang menyimpang yang dapat melanggar aturan hukum yang berlaku baik di lingkungan masyarakat secara umum maupun di lingkungan kampus.

Berdasarkan pemaparan tersebut, maka dirasa penting untuk mengetahui bagaimana penguatan pengetahuan kewarganegaraan (civic knowledge) sebagai upaya meningkatkan kesadaran hukum mahasiswa melalui pembelajaran Mata Kuliah Wajib Umum Pendidikan Kewarganegaan khususnya di Prodi PJKR (Pendidikan Jasmani Kesehatan dan Rekreasi) STKIP Pasundan.

\section{METODE}

Lingkup Penelitian dalam penelitian ini adalah penguatan pengetahuan kewarganegaraan (civic knowledge) sebagai upaya meningkatkan kesadaran hukum mahasiswa. Teknik pengumpulan data yang didalamnya terdiri atas studi kepustakaan, dalam hal ini mempelajari dan menganalisis berbagai literatur yang berkaitan dengan pengetahuan kewarganegaraan dalam upaya meningkatkan kesadaran hukum mahasiswa di STKIP Pasundan. Selain itu, dilakukan pula studi lapangan, yaitu observasi, wawancara dan dokumentasi.

Metode peneliti yang digunakan yaitu pendekatan kualitatif dengan metode deskriptif, dengan menggunakan pendekatan kualitatif dengan metode deskriptif, penulis dapat memperoleh pemahaman mengenai kajian tentang penguatan pengetahuan kewarganegaraan (civic knowledge) sebagai upaya meningkatkan kesadaran hukum mahasiswa. Alasan penggunaan metode ini karena akan memudahkan dalam pengambilan data yang sedang diteliti, pendekatan kualitatif dengan metode deskriptif dengan teknik pengumpulan data yaitu wawancara, observasi, studi dokumentasi dan studi literatur akan memudahkan peneliti dalam proses penelitian yang sedang diteliti.

\section{HASIL DAN PEMBAHASAN}

\section{Penguatan Pengetahuan Kewarganegaraan Melalui Mata Kuliah Pendidikan Kewarganegaraan dalam Upaya Meningkatkan Kesadaran Hukum Mahasiswa.}

Berdasarkan hasil wawancara terhadap narasumber didapatkan hasil mengenai pandangan tentang pengetahuan kewarganegaraan dalam meningkatkan kesadaran hukum mahasiswa di 
STKIP Pasundan, hasil penelitian menunjukkan bahwa pengetahuan kewarganegaraan dalam meningkatkan kesadaran hukum hal tersebut tergantung dari bagaimana sikap individu tersebut sadar kemudian melaksanakan taat/patuh terhadap peraturan yang berlaku maka yang perlu dibangun bukan hanya sekadar pengetahuan saja tetapi harus dibangun konsekuensi dari aturan yang ada. Dengan demikian konsekuensi terhadap peraturan dapat berupa sanksi, yang dimana bila suatu aturan yang telah disepakati dilanggar maka si pelanggar akan mendapat sanksi yang tegas, hal tersebut sejalan dengan pendapat Kansil (1986, pp. 38-39) yang mengemukakan beberapa unsur hukum tersebut meliputi:

a. Peraturan mengenai tingkah laku manusia dalam pergaulan masyarakat.

b. Peraturan diadakan oleh badan-badan resmi yang berwajib;

c. Peraturan itu bersifat memaksa;

d. Sanksi terhadap pelanggaran peraturan tersebut adalah tegas.

Dengan demikian suatu hukum dapat dipatuhi bilamana memang konsekuensi dari aturan yang dilanggar adalah tegas, sehingga kecenderungan seseorang untuk mematuhi hukum lebih tinggi karena sanksi yang berlaku di dalam aturan tersebut.Selanjutnya berdasarkan wawancara dengan narasumber diperoleh hasil penelitian bahwa kesadaran hukum mahasiswa STKIP Pasundan sendiri sudah tergolong baik dapat dilihat dari bagaimana para mahasiswa patuh dan taat terhadap aturan yang berlaku di STKIP Pasundan. Hal tersebut didasarkan karena mau tidak mau, suka tidak suka mahasiswa harus mentaati setiap peraturan yang sedari awal sudah disepekati dengan demikian maka terlihat bahwa sifat hukum itu memaksa hal tersebut serupa dengan pendapat Kansil \& Kansil (2011, p. 35) mengemukakan bahwa

Hukum itu bersifat mengatur dan memaksa. Ia merupakan peraturan-peraturan hidup kemasyarakatan yang dapat memaksa orang supaya menaati tata tertib dalam masyarakat serta memberikan sanksi yang tegas (berupa hukuman) terhadap siapa pun yang tidak mau patuh menaatinya.

Hasil penelitian juga menunjukkan bahwasanya terjadi perbedaan kepatuhan atau ketaatan terhadap hukum didasarkan pada tempat. Mahasiswa cenderung lebih mematuhi aturan yang ada di lingkungan kampus, sedangkan untuk diluar kampus masih ada yang melanggar kaidah-kaidah hukum yang berlaku.Hal tersebut didasarkan karena mahasiswa cenderung patuh/taat ketika ada figure atau orang yang ditakuti disegani. Sejalan dengan hal tersebut Afriliana (Digdani, 2012, p. 39) mengemukakan bahwa kesadaran hukum timbul karena beberapa faktor, faktor-faktor kesadaran hukum tersebut diantaranya
a. Rasa takut pada sanksi;
b. Memelihara hubungan baik dengan kelompok;
c. Memelihara hubungan baik dengan penguasa;
d. Kepentingan pribadi terjamin;
e. Sesuai dengan nilai yang dianut. 
Dengan demikian maka seseorang bisa saja mentaati hukum karena mereka memang tidak mau bermasalah dengan orang lain atau menjaga agar memelihara hubungan baik dengan penguasa jika dalam lingkungan kampus bisa dosen, rektor maupun sivitas akademi yang lainnya. Pada umumnya kesadaran hukum dikaitkan dengan ketaatan atau kepatuhan hukum. Kesadaran hukum masyarakat identik dengan ketaatan masyarakat terhadap hukum. Menurut Kelman dan Pospisil (Kenedi, 2015, p. 207) ada tiga jenis ketaatan, yaitu

a. Ketaatan yang bersifat compliance, yaitu jika seseorang menaati suatu aturan, hanya karena takut terkena sanksi. Kelemahan ketaatan jenis ini, karena membutuhkan pengawasan yang terus-menerus;

b. Ketaatan yang bersifat identification, yaitu jika seseorang menaati suatu aturan, hanya karena takut hubungan baiknya dengan pihak lain menjadi rusak; dan

c. Ketaatan yang bersifat internalization, yaitu jika seseorang menaati suatu aturan, benar-benar karena merasa bahwa aturan itu sesuai dengan nilai-nila intrinsik yang dianut nya.

Dengan demikian dapat diartikan bahwa seseorang bersikap patuh terhadap kaidah-kaidah hukum bukan saja karena satu alasan, akan tetapi karena dilatarbelakangi oleh berbagai alasan dan beberapa alasannya seperti yang sudah di paparkan diatas. Selanjutnya mengenai penguatan pengetahuan kewarganegaraan (civic knowledge) melalui mata kuliah pendidikan kewarganegaraan dalam upaya meningkatkan kesadaran hukum mahasiswa.Berdasarkan hasil wawancara terhadap narasumber ESmengemukakanbahwasanya penguatan pengetahuan kewarganegaraan (civic knowledge) dalam meningkatkan kesadaran hukum mahasiswa tersebut merupakan langkah yang strategis karena dengan penguatan pengetahuan yang didapat melalui mata kuliah pendidikan kewarganegaraan tersebut dapat meningkatkan pengetahuan kewarganegaraan mahasiswa yang dimana implementasi atau pembelajaran di kelas didukung dengan sumber-sumber atau literatur yang update serta relevan. Dalam segi meningkatkan kesadaran hukum pengetahuan harus dibarengi dengan pembiasaan atau habituasi baik di lingkungan rumah, masyarakat dan lingkungan kampus.

Sejalan dengan hal tersebut, kesadaran erat kaitannya dengan kepatuhan terhadap kaidahkaidah hukum pada umumnya menjadi pusat perhatian terutama mengenai basis-basis dasar kepatuhan seseorang yang dimana hal ini dikemukakan oleh Bierstedt (Surya R. A., 2016, p. 50) membaginya ke dalam empat dasar yaitu

\section{a. Indoctrination}

Sebab pertama mengapa warga masyarakat mematuhi kaidah-kaidah hukum adalah karena dia diindoktrinir untuk berbuat demikian. Sejak kecil manusia telah dididik agar mematuhi kaidah-kaidah yang berlaku dalam masyarakat. Sebagaimana halnya dengan unsur-unsur kebudayaan lainnya, maka kaidah-kaidah telah ada waktu seseorang dilahirkan. Dan semula manusia menerimanya secara tidak sadar. Melalui proses 
sosialisasi manusia dididik untuk mengenal, mengetahui, serta mematuhi kaidah-kaidah tersebut

b. Habituation

Oleh karena sejak kecil mengalami proses sosialisasi, maka lama kelamaan menjadi suatu kebiasaan untuk mematuhi kaidah-kaidah yang berlaku. Memang pada mulanya sukar sekali untuk mematuhi kaidah-kaidah tadi yang seolah-olah mengekang kebebasan. Akan tetapi apabila hal tersebut setiap hari ditemui, maka lama kelamaan menjadi suatu kebiasaan untuk mematuhinya terutama apabila manusia sudah mulai mengulangi perbuatan-perbuatannya dengan bentuk dan cara yang sama.

c. Utility

Pada dasarnya manusia mempunyai kecenderungan untuk hidup pantas dan teratur. Akan tetapi apa yang pantas dan teratur untuk seseorang belum tentu pantas dan teratur bagi orang lain. Oleh karena itu diperlukan suatu patokan tentang kepantasan dan keteraturan tersebut. Patokan tadi merupakan pedoman-pedoman tentang tingkah laku dan dinamakan kaidah. Dengan demikian, maka salah satu faktor yang menyebabkan orang taat pada kaidah adalah karena kegunaan dari pada kaidah tersebut. Manusia menyadari bahwa apabila dia hendak hidup pantas dan teratur maka diperlukan kaidah-kaidah.

d. Group identification

Salah satu sebab mengapa seseorang patuh pada kaidah, adalah karena kepatuhan tersebut merupakan salah satu sarana untuk mengadakan identifikasi dengan kelompok. Seseorang mematuhi kaidah-kaidah yang berlaku dalam kelompoknya bukan karena dia menganggap kelompoknya lebih dominan dari kelompok-kelompok lainnya, akan tetapi justru karena ingin mengadakan identifikasi dengan kelompoknya tadi.

Dengan demikian dapat terlihat bahwa salah satu dasar mengapa seseorang taat atau patuh terhadap peraturan atau kaidah-kaidah hukum salah satunya adalah dengan habituation atau kebiasaan. Selanjutnya berdasarkan wawancara terhadap narasumber juga diperoleh bahwa untuk meningkatkan kesadaran hukum perlu adanya kesearahan antara civic knowledge, civic skills dan civic disposition.

Branson (Komalasari, 2011, p. 186) mengemukakan bahwa pengetahuan kewarganegaraan (civic knowledge) berkaitan dengan kandungan atau apa yang seharusnya diketahui oleh warga negara.Muchtarom (2012, p. 120)mengemukakan bahwa keterampilan kewarganegaraan (civic skills) meliputi keterampilan intelektual (intellectual skills) dan keterampilan berpartisipasi (participatory skills) dalam kehidupan berbangsa dan bernegara. Contoh keterampilan intelektual adalah keterampilan dalam merespons berbagai persoalan politik, misalnya merancang dialog dengan DPRD. Contoh keterampilan berpartisipasi adalah keterampilan menggunakan hak dan kewajibannya di bidang hukum, misalnya segera melapor kepada polisi atas terjadinya kejahatan yang diketahui.

Muchtarom (2012, p. 120) mengemukakan bahwa "Watak kewarganegaraan (civic dispositions) sesungguhnya merupakan dimensi yangpaling substantif dan esensial dalam mata pelajaran Pendidikan Kewarganegaraan. Dimensi watak/ karakter kewarganegaraan dapat dipandang sebagai "muara" dari pengembangan kedua dimensi sebelumnya." 
Dengan demikian untuk meningkatkan kesadaran hukum tersebut hal yang perlu dibangun bukan hanya sebatas pengetahuan saja tetapi harus pula dibangun civic skills serta civic knowledge. Selanjutnya dari hasil wawancara terhadap narasumber juga diperoleh bahwa materimateri mata kuliah pendidikan kewarganegaraan sendiri dirasa cukup dalam memberikan pengetahuan tentang hukum meskipun tidak secara spesifik namun setidaknya melalui mata kuliah pendidikan kewarganegaraan ini dapat memberikan pemahaman tentang pentingnya kesadaran akan hukum karena dalam mata kuliah pendidikan kewarganegaraan pun diperkenalkan teori warga negara yang baik. Sejalan dengan hal tersebut warga negara yang baik menurut Azis Wahab (Sofyan \& Dadang, 2015, p. 185) ialah

Warga negara yang memahami dan mampu melaksanakan dengan baik hak-hak dan kewajibannya sebagai individu warga Negara yang memiliki kepekaan dan tanggung jawab sosial, mampu memecahkan masalah-masalahnya sendiri dan juga masalah-masalah kemasyarakatan secara cerdas sesuai dengan fungsi dan perannya (socially sensitive, socially responsible, dan socially intelligence), memilki sikap disiplin pribadi, mampu berfikir kritis kreatif, dan inovatif agar dicapai kualitas pribadi dan perilaku warga Negara dan warga masyarakat yang baik (socio civic behavior dan desirable personal qualities).

Dengan demikian, dapat terlihat bahwa warga negara yang baik adalah warga negara yang mampu melaksanakan dengan baik hak-hak serta kewajiban-kewajibannya sebagai warga negara, dan salah satu kewajiban warga negara adalah menjunjung tinggi hukum dimana juga sejalan dengan yang tercantum dalam Pasal 27 ayat (1) UUD NRI 1945 berbunyi: "Segala warga negara bersamaan kedudukannya di dalam hukum dan pemerintahan dan wajib menjunjung hukum dan pemerintahan itu dengan tidak ada kecualinya". Sejalan dengan hal tersebut Cogan (Sukmayadi , 2016, p. 97) berpendapat bahwa sebagai warga negara yang baik/warga negara seutuhnya memilikisejumlah ciri utama, yaitu

a. Rasa kepribadian/jati diri mandiri (a sense of identity), baik sebagai insan ilahiah, sosial, maupun kebangsaan. Ciri mandiri ini dapat dilihat dari berbagai dimensi (geografis, etnis, dan agama), serta mampu menuju kehidupan yang globalistik.

b. Rasa nikmat akan sejumlah haknya baik legal, political dan sosio-economical rights, serta mampu menjalankan secara baik dan benar.

c. Rasa tanggung jawab akan kewajiban-kewajiban (obligation) yang menjadi keharusannya, sehingga selalu menjaga keseimbangan antara kepentingan public dengan privat, serta menjelmakan tanggung jawab (responsibility) menjadi kewajiban (obligation) dan tugas keharusan(duties).

d. Minat dan keterlibatan akan public affairs (kepentingan umum) sehingga sikap, mau, dan mampu berpartisipasi secara aktif, kreatif, positif/konstruktif, dan demokratis.

e. Kemampuan untuk menyerap/ menerima nilai-nilai dasar kemasyarakatan (basic societal values); sehingga mampu menjalin dan membina kerja sama, kejujuran, kedamaian, serta rasa cinta dan kebersamaan dalam mempersiapkan hari esok (futuristic orientation).

Dengan demikian terlihat bahwa salah satu ciri warga negara yang baik memiliki rasa tanggung jawab akan kewajiban-kewajibannya sebagai warga negara. Maka dengan demikian 
jelaslah bahwa sebagai warga negara yang baik kita harus dapat mentaati setiap hukum yang ada dan berlaku. Salah satu usaha menanamkan kesadaran hukum adalah dengan memberikan pendidikan hukum yang dimana untuk pendidikan hukum sendiri sudah terintegrasi dalam pembelajaran pendidikan kewarganegaraan. Sehingga, pada akhirnya terwujdunya kesadaran hukum adalah terciptanya ketertiban dan kedamaian dalam kehidupan bermasyarakat.

\section{Kendala yang Dihadapi dalam Pembelajaran Pendidikan Kewarganegaraan sebagai Sarana Penguatan Pengetahuan Hukum dalam Meningkatkan Kesadaran Hukum Mahasiswa.}

Hasil penelitian menunjukkan mengenai kendala yang dihadapi dalam pembelajaran pendidikan kewarganegaraan sebagai sarana penguatan hukum dalam meningkatkan kesadaran hukum mahasiswa. Berdasarkan hasil penelitian terhadap dosen dosen Pendidikan Kewarganegaraan mengemukakan bahwa kendala yang dihadapi di Prodi PJKR dalam pembelajaran mata kuliah pendidikan kewarganegaraan adalah waktu pembelajaran yang hanya 2 sks atau satu semester, buku-buku atau sumber literatur yang kurang update, kehadiran mahasiswa yang tidak full mengikuti mata kuliah pendidikan kewarganegaraan karena dispensasi.

Selanjutnya, diperoleh temuan bahwa upaya yang dilakukan dalam penguatan hukum di kelas salah satunya dengan mendisiplinkan diri serta membuat aturan di kelas yang dibarengi dengan konsekuensi bilamana aturan yang sudah disepakati dilanggar. Adapun Strategi pembelajaran yang tepat yang dapat digunakan dalam kelas mata kuliah pendidikan kewarganegaraan salah satunya dapat berupa metode pembelajaran dengan metode Contextual Teaching and Learning sebagaimana yang diungkapkan oleh Johnson (2010, p. 67) yang mengemukakan bahwa

Sistem CTL adalah sebuah proses pendidikan yang bertujuan menolong para siswa melihat makna di dalam materi akademik yang mereka pelajari dengan cara menghubungkan subjek-subjek akademik dengan konteks dalam kehidupan keseharian mereka, yaitu dengan konteks keadaan pribadi, sosial dan budaya mereka. Untuk mencapai tujuan ini, sistem tersebut meliputi delapan komponen berikut: membuat keterkaitan-keterkaitan yang bermakna, melakukan pekerjaan yang berarti, melakukan pembelajaran yang diatur sendiri, melakukan kerja sama, berpikir kritis dan kreatif, membantu individu untuk tumbuh dan berkembang, mencapai standar yang tinggi, dan menggunakan penilaian autentik.

\section{SIMPULAN}

Berdasarkan hasil penelitian terhadap penguatan pengetahuan kewarganegaraan (civic knowledge) sebagai upaya meningatkan kesadaran hukum mahasiswa melalui mata kuliah pendidikan kewarganegaraan di STKIP Pasundan, peneliti dapat mengambil kesimpulan sebagai berikut: 
1. Pandangan tentang pengetahuan kewarganegaraan dalam meningkatkan kesadaran hukum mahasiswa di STKIP Pasundan, hasil penelitian didapatkan kesimpulan bahwa pengetahuan kewarganegaraan dalam meningkatkan kesadaran hukum hal tersebut tergantung dari bagaimana sikap individu tersebut sadar kemudian melaksanakan taat/patuh terhadap peraturan yang berlaku maka yang perlu dibangun bukan hanya sekadar pengetahuan saja. Untuk kesadaran hukum mahasiswa STKIP Pasundan sendiri sudah tergolong baik dapat dilihat dari bagaimana para mahasiswa patuh dan taat terhadap aturan yang berlaku di STKIP Pasundan. Hasil penelitian juga menunjukkan bahwasanya terjadi perbedaan kepatuhan atau ketaatan terhadap hukum didasarkan pada tempat. Mahasiswa cenderung lebih mematuhi aturan yang ada di lingkungan kampus, sedangkan untuk diluar kampus masih ada yang melanggar kaidah-kaidah hukum yang berlaku.

2. Penguatan pengetahuan kewarganegaraan (civic knowledge) melalui mata kuliah pendidikan kewarganegaraan dalam upaya meningkatkan kesadaran hukum mahasiswa. Dari hasil penelitian didapatkan kesimpulan bahwasanya penguatan pengetahuan kewarganegaraan (civic knowledge) dalam meningkatkan kesadaran hukum mahasiswa tersebut merupakan langkah yang strategis karena dengan penguatan pengetahuan yang didapat melalui mata kuliah pendidikan kewarganegaraan tersebut dapat meningkatkan pengetahuan kewarganegaraan mahasiswa yang dimana implementasi atau pembelajaran di kelas didukung dengan sumber-sumber atau literatur yang update serta relevan. Dalam segi meningkatkan kesadaran hukum pengetahuan harus dibarengi dengan pembiasaan atau habituasi baik di lingkungan rumah, masyarakat dan lingkungan kampus. Untuk meningkatkan kesadaran hukum perlu adanya kesearahan antara civic knowledge, civic skills dan civic disposition. Materi-materi mata kuliah pendidikan kewarganegaraan dirasa cukup dalam memberikan pengetahuan tentang hukum meskipun tidak secara spesifik namun setidaknya melalui mata kuliah pendidikan kewarganegaraan ini dapat memberikan pemahaman tentang pentingnya kesadaran akan hukum karena dalam mata kuliah pendidikan kewarganegaraan pun diperkenalkan teori warga negara yang baik.

3. Kendala yang dihadapi dalam pembelajaran pendidikan kewarganegaraan sebagai sarana penguatan hukum dalam meningkatkan kesadaran hukum mahasiswa. Dari hasil penelitian didapati kesimpulan bahwasanya kendala yang dihadapi di Prodi PJKR dalam pembelajaran mata kuliah pendidikan kewarganegaraan adalah waktu 
pembelajaran yang hanya 2 sks atau satu semester, buku-buku atau sumber literatur yang kurang update, kehadiran mahasiswa yang tidak full mengikuti mata kuliah pendidikan kewarganegaraan karena dispensasi. Upaya yang dilakukan dalam penguatan hukum di kelas salah satunya dengan mendisiplinkan diri serta membuat aturan di kelas yang dibarengi dengan konsekuensi bilamana aturan yang sudah disepakati dilanggar. Strategi pembelajaran yang tepat yang dapat digunakan dalam kelas mata kuliah pendidikan kewarganegaraan salah satunya dapat berupa metode pembelajaran dengan metode Contextual Teaching and Learning.

4. Pengetahuan kewarganegaraan perlu disertai dengan pengaplikasian pengetahuan yang dimiliki dalam kehidupan sehari-sehari sehingga dalam proses penguatan pengetahuan kewarganegaraan melalui proses pembelajaran pendidikan kewarganegaraan tersebut peran dosen sangatlah penting untuk dapat mencipta suasana kelas mata kuliah pendidikan kewarganegaraan menjadi lebih menarik yang dapat memotivasi serta mendorong keaktifan mahasiswa dalam kelas pendidikan kewarganegaraan sehingga dapat memicu mahasiswa dalam mengaplikasikan hasil pembelajaran pendidikan kewarganegaraan dalam kehidupan sehari-hari khususnya dalam hal kesadaran hukum mahasiswa.

\section{DAFTAR PUSTAKA}

Arliman, L. (2015). Penegak Hukum dan Kesadaran Masyarakat. Yogyakarta: Deepublish.

Aryani, I. K., \& Susatim, M. (2010). Pendidikan Kewarganegaraan Berbasis Nilai. Bogor: Ghalia Indonesia.

Badan Pembinaan Hukum Nasional. (2016, Oktober Sabtu). Badan Pembinaan Hukum Nasional Kementrian Hukum dan HAM Republik Indonesia. Retrieved Juli Senin, 2018, from Badan Pembinaan Hukum Nasional Kementrian Hukum dan HAM Republik Indonesia: https://www.bphn.go.id/news/201610210052066/Yuliawiranti-Peningkatan-KesadaranHukum-Harus-Dimulai-dari-Pendidikan

Digdani, T. K. (2012). Kesadaran Hukum Masyarakat Dalam Pembuatan Surat Izin Mengemudi (SIM) C di Kelurahan Limbangan Wetan Kecamatan Brebes Kabupaten Brebes. Skrpisi. Purwokerto: Fakultas Hukum Universitas Jendral Soedirman.

Dwiyatmi, S. H., Sulasmono, B. S., Raharjo, W., Kustadi, Kurnia, T. S., Rauta, U., et al. (2012). Pendidikan Kerwarganegaraan . Yogyakarta: Pustaka Pelajar.

Erwin, M. (2012). Pendidikan Kewarganegaraan Republik Indonesia . Bandung: PT Refika Aditama.

Hardianto, O. (2017). Peran Pendidikan Kewarganegaraan Dalam Meningkatkan Kesadaran Hukum Berlalu Lintas di Jalan Raya (Studi Kasus di SMA Negeri Lembang Kelas XII). Bandung: FKIP UNPAS. 
Johnson, E. B. (2010). CTL (Contextual Teaching \& Learning) Menjadikan Kegiatan BelajarMengajar Mengasyikan dan Bermakna. Bandung: Kaifa .

Kansil, C. (1986). Pengantar Ilmu Hukum dan Tata Hukum Indonesia. Jakarta: Balai Pustaka.

Kansil, C. S., \& Kansil, C. (2011). Pengantar Ilmu Hukum Indonesia. Jakarta: Rineka Cipta.

Kenedi, J. (2015). Studi Analisis Terhadap Nilai-nilai Kesadaran Hukum dalam Pendidikan Kewarganegaraan (Civic Education) di Perguruan Tinggi Islam. Jurnal Madania, 205215.

Komalasari, K. (2011). Kontribusi Pembelajaran Kontekstual untuk Pengembangan. MIMBAR, 47-55.

Maftuh, B. (2008). Internalisasi Nilai-nilai Pancasila dan Nasionalisme Melalui Pendidikan Kewarganegaraan. Educationist, 134-144.

Moleong , L. (2007). Metode Penelitian Kualitatif. Bandung: PT Rosdakarya Offest.

Muchtarom, M. (2012). Strategi Penguatan Nilai-Nilai Pancasila Melalui Inovasi Pembelajaran Pkn Berorientasi Civic Knowledge,Civic Disposition, Dan Civic Skill Di Perguruan Tinggi. Pkn Progresif, 115-130.

Pemerintah Republik Indonesia. (1945). Undang-Undang NRI 1945. Jakarta: Negara Kesatuan Republik Indonesia.

Pemerintah Republik Indonesia. (2012). Undang-Undang Republik Indonesia Nomor 12 Tahun 2012 Tentang Pendidikan Tinggi. Jakarta: Negara Republik Indonesia.

Rusniati. (2015). Pendidikan Nasional dan Tantangan Globalisasi: Kajian kritis terhadap pemikiran A. Malik Fajar. Jurnal Ilmiah DIDAKTIKA, 105-128.

Sari, Y. M. (2014). Pembinaan Toleransi dan Peduli Sosial dalam Upaya Memantapkan Watak Kewarganegaraan Civic Disposition Siswa . Jurnal Pendidikan Ilmu Sosial, 15-26.

Sofyan, F. S., \& Dadang, S. (2015). Hubungan Mata Kuliah Pendidikan Kewarganegaraan Dengan Peningkatkan Wawasan Kebangsaan dan Semangat Nasionalisme Mahasiswa. Jurnal Pendidikan Ilmu Sosial , 185-199.

Sugiyono. (2016). Metode Penelitian Kuantitatif Kualitatif $R \& D$. Bandung : Alfabeta .

Sukmayadi , T. (2016). Kajian Tentang Karakter Berbasis Nilai-Nilai Kearifan Lokal Pada Masyarakat Adat Kampung Kuta Kecamatan Tambaksari Kabupaten Ciamis. Jurnal Civics.

Surya, R. A. (2016). Problematika Kesadaran Hukum Pengendara Sepeda Motor Terhadap Persyaratan Teknik dan Layak Jalan Kendaraan Motor Roda Dua Dihubungkan Dengan Undang-undang No 22 Tahun 2009 Tentang Lalu Lintas Dan Angkutan Jalan Di Kota Bandung. Skripsi. Bandung: Fakultas Hukum Unpas.

Ubaedillah, A., Rozak, A., Hanas, A. S., Darmadji, A., Irfan, A., Budiman, et al. (2010). Pendidikan Kewargaan . Jakarta: Kencana. 